\title{
SODVELON News, Events and Transactions
}

1. The $37^{\text {th }}$ GBM of SODVELON took place at BPKIHS, Dharan on $28^{\text {th }}$ Falgun, 2067 (12th March, 2011). Election for the 10th Executive committee was conducted. Prof. Dr. Sudha Agrawal was elected the president of SODVELON. Other executive members were elected unanimously.

Dr. HN Gupta- Immediate Past President, Dr. Shristi Shrestha- Vice President, Dr. Sudip Parajuli- General Secretary, Dr. Rima Shrestha-Treasurer, Dr. Ghanashyam JhaJoint Secretary, Dr. Sabina Bhattarai- Chief Editor, Dr. Rushma Shrestha - Member, Dr. Upama Paudel- Member

2. Subsequently as a regular academic event of SODVELON 3 CME programs were organized during the year 2067/2068

I. On 16 ${ }^{\text {th }}$ Baisakh 2068 (29th April 2011) a CME on 'From mushrooms to cutaneous Lymphomas' was organized by the Society at TU Teaching Hospital. The CME was jointly organized by the Society of Dermatologists and Pathologists of Nepal and was first of its kind where two societies were mutually inolved. Prof. Gunter Burg from Switzerland delivered the speech on the topic. The program was sponsored by ZYG Pharmaceuticals Pvt. Ltd

II. On 23rd Bhadra 2068 a CME on "A combined approach to the Chromoblastomycosis" was organized by the society at Hotel Mountain. The speaker was Dr. Prassana on behalf of Dr. Ajay Kumar, Assistant Professor, Manipal Teaching Hospital. The program was sponsored by Panas Pharmaceuticals Pvt Ltd.

III.On $3^{\text {rd }}$ Mangsir $2068(19 / 11 / 2011)$ a symposium for "Psoriasis and atopic dermatitis" was organized in Hotel deLA Annapurna. The speakers for the program were Dr. Anil Kumar Das, Dr. BMM Kayastha, Dr. DP Shrestha, Dr. Murlidhar Rajgopalan, Dr. Rajeev Sekhri, Dr. Sushil Tahiliani, Dr. Sudha Agrawal and Dr. Vinoo Sekhri) The program was sponsored by Fulford India.

3. From $28^{\text {th }}$ falgun till date, eleven Dermatologists ( Dr. Sanjeev Gupta, Dr. Bipin Bhattachan, Dr. Laila Lama Tangbetani, Dr. Jameel Akhtar Mikrani, Dr. Nitesh Raj Pokhrel, Dr. Bijay Shrestha, Dr. Anu Agrawal, Dr. Sushil Paudel, Dr. Manish Pradhan, Dr. Aparna Shah and Dr. Utsav Sharma ) have been awarded Life Membership of SODVELON.

Associate membership was given to 4 residents and renewal of associate membership was done for 11 residents. So till date there are 86 life members, 2 ordinary members and 15 associate members.

4. Furthermore, web page of the society is ready. We can visit to view our web page. The web page contains announcements, events and calendar, List of life members, list of past executive members, and present executive committee, membership benefit form. For now onwards one can apply for membership of the society by downloading the form from the web page.

5. Regarding the journal NJDVL, one issue, that is Volume 9(Printed as volume 10), with lot of other printing errors, has been re printed this year. The cost of the printing was borne by the society.

A new editorial board has been formed for NJDVL. This board consists of following members. Dr Sabina Bhattarai, Editor- in -chief, Dr Dipendra Gurung, Dr. Nidhi Shah, Dr Sagar Mani Jha, Dr. Ajay Kumar, Dr. Chadni Kharel and Dr. Upama Paudel as editors, Dr. Sonia Gupta and Dr. Astha Pant as assistant editors, DD Baral as 
biostatician and Dr. Sudip Parajuli as managing editor.

Besides this a national advisory board have been formed which consists of following members: Dr. RB Adiga, Dr. NK Singh, Dr. VB Rajbhandari, Prof. AK Jha, Prof DB Pokhrel, Prof. DP Shrestha, Prof. Sudha Agrawal, Prof. BMM Kayastha, Dr. Arpana Rijal, Dr Govinda Pokhrel, and Dr. Dharmendra Karn.

In addition to this a list of international

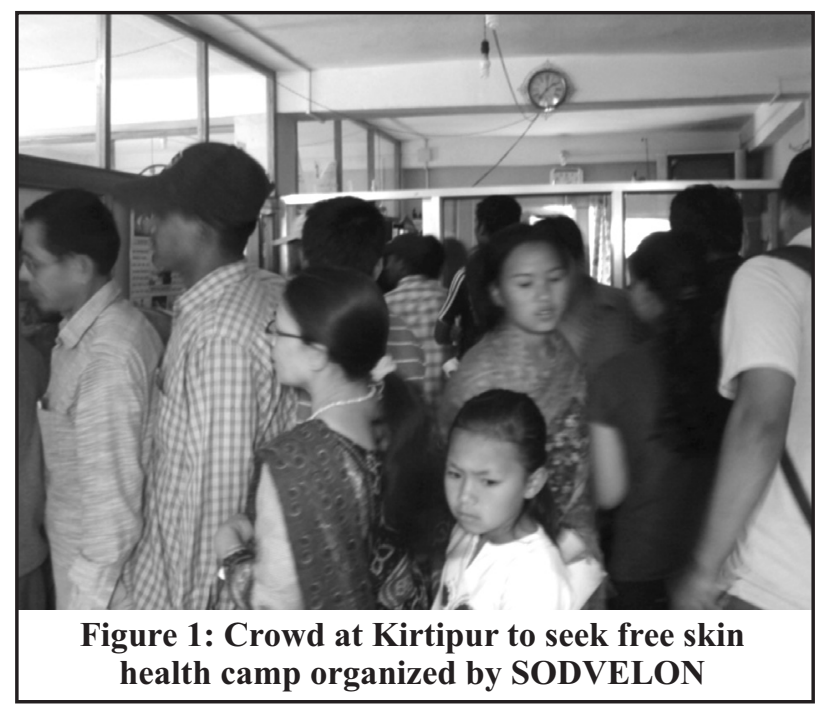

advisory board have been formed which consists of following members: Prof. D M Thappa (India), Prof. KK Verma (India), Prof. SS Pandey (India), Prof. Christa Prins (Switzerland), Dr. Nayera Moftah (Egypt) and Prof. Gunter Berg (Switzerland).A heartily thank to all of them for giving their consent

Moreover, NJDVL is on the process of indexing and is already online. You can download the journal from the site of Nepal Journal online. For this purpose ISSN number (ISSN: 2091-167X-online) has already been received.

On behalf of SODVELON, special thanks and appreciation goes to the editorial team for their enthusiasm and effort in updating journal.

6. A SARAD conference was held in Bangladesh on $2^{\text {nd }} / 3^{\text {rd }}$ of December of
2011. Following members of the SODVELON were nominated in the executive committee of SARAD; Prof. AK Jha- member, Prof. Sudha Agrawalmember, and Dr. Shristi Shrestha Treasurer. Prof. AK Jha was elected as advisor of present SARAD executive. On the same occasion a momento was presented to 7 th SARCD from SODVELON.

7. Dr. Harendra Kumar Jha received 2012 American Academy of Dermatology Poster exhibit schlolarship. On behalf of the society let us congratulate him for this award.

8. Also, for nomination of ILDS certificate of appreciation, criterias were formed according to the format send by ILDS. Prof. DB Pokhrel has been nominated for the award from our society.

9. It is to inform all the members of the society that a sum of Rs. 10, 000 will be provided to the best paper in SODVELONCON each year. This best paper will be categorized in two headings; One presented by the life member and the other for the post graduate residents. Of this amount Rs. 7000 will be separated for the best oral presentation to the life member of the society working in the field of research. Remaining Rs. 3000 will be separated for the best research paper

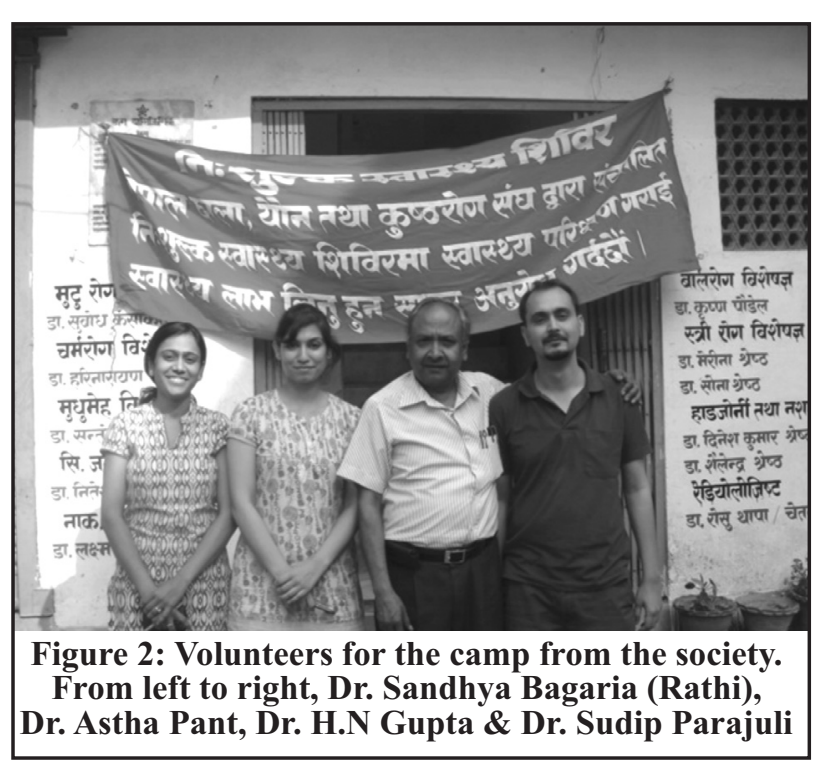


presentation in the conference by postgraduate students. The award will be provided by Surbhitam Pharmaceutical Pvt. Ltd.

10. Our ILDS membership has been renewed till 2013.

11. Accounts: Prof. Sudha has handed over 1.75 lakhs to the society from the VIIth SODVELONCON.

It is also to inform you all that Rs 70, 000 was transferred from 6th SARCD and SODVELONCON 7th 2009 to SARAD account. Remaining amount was transferred to SODVELON account.

Renewal and auditing for the fiscal year 2067/ 2068 has been completed. The land owned by the society has been included as the asset of the society and included in the audit report of of year 2067/2068.

12. As a part of regular activity of SODVELON, a free skin health camp was organized by the Society at Kirtipur on $5^{\text {th }}$ May 2012. In this camp, 195 patients of skin diseases were examined and drugs were distributed free of charge. Dr. Sudip Parajuli, Dr. Astha Pant, Dr. Sandhya Bagariya(Rathi), Dr. Sushil Paudel, and Dr. H.N Gupta participated in the camp.

\author{
Dr. Sudip Parajuli, MBBS, MD
} General Secretary, SODVELON 